\title{
Novel 1- $O$-indole-3-acetyl- $\beta$-D-glucose-dependent acyltransferase transferring indoleacetyl moiety to some mono- di- and oligosaccharides
}

\author{
Ewelina Starzyńska $\cdot$ Stanisław Kowalczyk
}

Received: 18 February 2011/Revised: 13 May 2011/Accepted: 14 June 2011/Published online: 1 July 2011

(C) The Author(s) 2011. This article is published with open access at Springerlink.com

\begin{abstract}
O-(indole-3-acetyl)- $\beta$-D-glucose: sugar indoleacetyl transferase (1-O-IAGlc-SugAc) is a novel enzyme catalyzing the transfer of the indoleacetyl (IA) moiety from 1 - $O$-(indole-3-acetyl)- $\beta$-D-glucose to several saccharides to form ester-linked IAA conjugates. 1-O-IAGlc-SugAc was purified from liquid endosperm of Zea mays by fractionation with ammonium sulphate, anion-exchange, Blue Sepharose chromatography, affinity chromatography on Concanavalin A-Sepharose, adsorption on hydroxylapatite and preparative PAGE. The obtained enzyme preparation indicates only one band of $R_{\mathrm{f}} 0.67$ on $8 \%$ non-denaturing PAGE consisting of two polypeptides of 42 and $17 \mathrm{kDa}$ in SDS/PAGE. Highly purified 1-O-IAGlc-SugAc shows maximum transferase activity with monosaccharides (mannose, glucose, and galactose), lower activity with disaccharides (melibiose, gentobiose) and trisaccharide (raffinose) and minimal enzymatic activity with oligosaccharides from the raffinose family as well. The novel acyltransferase exhibits, besides its primary indoleacetylation of sugar, minor hydrolytic and disproportionation activities producing free IAA and supposedly 1,2di-O-(indole-3-acetyl)- $\beta$-glucose, respectively. Presumably, 1-O-IAGlc-SugAc, like 1- $O$-indole-3-acetyl- $\beta$-D-glucosedependent myo-inositol acyltransferase (1-O-IAGlc-InsAc), is another member of the serine carboxypeptidase-like (SCPL) acyltransferase family.
\end{abstract}

Communicated by J. Ueda.

E. Starzyńska $(\bowtie) \cdot S$. Kowalczyk

Department of Biochemistry, Institute of General

and Molecular Biology, Nicholas Copernicus University,

Gagarina 7, 87-100 Torun, Poland

e-mail: e.starzynska@umk.pl

S. Kowalczyk

e-mail: kowalcz@umk.pl
Keywords Indole-3-acetic acid - 1-O-IA-glucose . 1-O-IA-glucose-dependent acyltransferases · Zea mays

$\begin{array}{ll}\text { Abbreviations } & \\ \text { IAA } & \text { Indole-3-acetic acid } \\ 1 \text { 1- } O \text {-IAGlc } & 1-O \text {-(indole-3-acetyl)- } \beta \text {-D-glucose } \\ \text { IAInos } & \text { Indole-3-acetyl-myo-inositol } \\ 1 \text { 1- } O \text {-IAGlc-InosAc } & 1-O \text {-(indole-3-acetyl)-glucose: } \\ & m y o \text {-inositol indoleacetyltransferase } \\ 1-O \text {-IAGlc-SugAc } & \begin{array}{l}1-O \text {-(indole-3-acetyl)-glucose: } \\ \text { sugar indoleacetyltransferase }\end{array} \\ & \text { Indole-3-acetic acid: } \\ \text { IAA-UGT } & \text { glucosyltransferase }\end{array}$

\section{Introduction}

Biochemical studies have shown that the conjugation of indole-3-acetic acid (IAA) to many kinds of molecules is part of a regulatory mechanism for controlling IAA levels through sequestration and reuse, or as an entry into IAA catabolism. In this respect, conjugates have been proposed to have roles in storing, transporting, and compartmentalizing auxin, as well as in detoxifying excess IAA and protecting the free acid against peroxidative degradation (Bandurski et al. 1995; Slovin et al. 1999; Ljung et al. 2002; Woodward and Bartel 2005). To date, a majority of the information on IAA conjugation has focused on IAA linked to a single amino acid, peptides, and proteins, as well as to glucose, myo-inositol or myo-inositol glycosides (Slovin et al. 1999; Woodward and Bartel 2005). Enzymes that conjugate IAA to amino acids are members of the firefly luciferase superfamily that comprise enzymes that 
adenylate various organic acids (Staswick et al. 2005). In Arabidopsis thaliana, rice, and some other plant species several members of the GH3 proteins family are able to conjugate IAA to amino acids through amide bonds (Staswick et al. 2005; Terol et al. 2006; Wang et al. 2008). In bean seeds (Phaseolus vulgaris), the auxin conjugates are also in amide linkage consisting of a series of peptides and proteins. These IAA conjugated polypeptides accumulate in seeds during development in correlation with storage protein accumulation (Walz et al. 2002; Seidel et al. 2006). The endosperm of kernels of Zea mays contains $97-99 \%$ of their endogenous IAA as ester conjugates (Epstein et al. 1980; Jensen and Bandurski 1994). One-half of the esterified IAA consists of esters of IAA and myoinositol or myo-inositol glycosides (Ueda and Bandurski 1974; Corcuera and Bandurski 1982; Corcuera et al. 1982; Chisnell 1984), and ca. one-half of the esters are the conjugates of IAA and cellulosic glucans (Piskornik and Bandurski 1972). The ester conjugates seem to predominate among monocotyledon plants (maize, rice), though their synthesis has also been found in Arabidopsis (Tam et al. 2000), immature bean seeds (Bialek and Cohen 1989; Jakubowska and Kowalczyk 2004), Scots pine seeds (Ljung et al. 2001), tomato pericarp (Catalá et al. 1992), henbane cells (Oetiker and Aeschbacher 1997) or tobacco leaf protoplasts (Caboche et al. 1984; Delbarre et al. 1994).

In maize, the pathway to the ester conjugates begins with the synthesis of the acyl alkyl acetal 1-O-(indole3 -acetyl)- $\beta$-D-glucose (1-O-IAGlc) (Michalczuk and Bandurski 1980, 1982) catalyzed by UDP-glucose: IAA glucosyltransferase (IAA-UGT).

IAA + UDP-glucose $\leftrightarrow$ 1-O-IAGlc + UDP

IAA-UGT was partially purified from kernels of sweet corn (Leźnicki and Bandurski 1988), and shortly after, the homogenous enzyme, as well the 18 -amino acid sequence of the N-terminal end, and polyclonal antibodies were obtained that were utilized to select a cDNA clone from a maize library (Kowalczyk and Bandurski 1991; Szerszen et al. 1994). More recently, an Arabidopsis gene encoding IAA-UGT was identified (Jackson et al. 2001), and transgenic Arabidopsis and tomato plants constitutively overexpressing Arabidopsis and maize genes have been obtained (Jackson et al. 2002; Iyer et al. 2005; LudwigMüller et al. 2005).

In vitro reaction synthesis of 1-O-IAGlc does not proceed beyond $25-30 \%$ due to the thermodynamic constraints of the reactants and products (Kowalczyk and Bandurski 1990), therefore in immature maize and rice seeds the energetically unfavourable reaction is followed by an energetically favourable transacylation of the IAA moiety from 1-O-IAGlc to myo-inositol:
1-O-IAGlc + myo-inositol $\rightarrow$ IA-myo-inositol + glucose

The synthesis of IA-myo-inositol (IAInos) was observed for the first time in extract of immature kernels of maize (Michalczuk and Bandurski 1980, 1982), and more recently, 1-O-IAGlc-dependent myo-inositol acyltransferase (1-OIAGlc-InosAc) was partially purified and characterized (Kęsy and Bandurski 1990). Not long ago, an electrophoretically homogenous enzyme, as well the amino acid sequence of 21-aa peptide was obtained (Kowalczyk et al. 2003), which was currently utilized to select a cDNA clone (submitted for publication).

1-O-IAGlc is an intermediate in the formation of IAInos in maize and rice seeds (Hall 1980), although the metabolic fate of this intermediate in other plants has yet to be identified. Given the high-energy status of 1-O-IAGlc, it can be assumed that it is a donor of IAA moiety in the formation of other ester conjugates as well. Years ago, a small amount of 2-O-, 4- $O$ and 6-O-(indole-3-acetyl)-Dglucopyranose, and IA-rhamnose esters were identified in mature sweet corn kernels, and in the floral parts of Peltophorum ferrugineum, respectively (Ehmann 1974; Ganguly et al. 1974). More recently, the synthesis of di-O(indole-3-acetyl)-D-glucose (disproportionation reaction) (Szmidt-Jaworska et al. 1997), and the production of the ester conjugates with some sugars of the raffinose family have been reported (Leźnicki and Bandurski 2001). Moreover, the results of our earlier work suggested that 1-O-IAGlc synthesized in immature legume seeds may be a donor of IAA moiety for the modification of some high molecular weight compounds (Jakubowska and Kowalczyk 2004), supposedly $1 \rightarrow 4$ cellulosic glucans or glycoproteins, earlier identified in maize and oat seeds (Piskornik and Bandurski 1972; Percival and Bandurski 1976).

This work is the first demonstration of novel 1-O-IAGlcdependent acyltransferase (1-O-IAGlc-SugAc) that in immature corn seeds efficiently transfers IAA moiety to monosaccharides (mannose, glucose, galactose), slower to disaccharides (melibiose, gentobiose) or trisaccharide (raffinose) and marginally to oligosaccharides containing a galactose unit linked via $(1 \rightarrow 6)$ glycosidic linkage at the non-reducing end.

\section{Materials and methods}

Plant material

Plants used for analysis were grown under field conditions during the summer of 2008. The liquid endosperm of Zea mays sweet corn was collected by cutting the rows of kernels with a razor blade and pressing out the kernel contents against the rim of a beaker chilled on ice. The 
liquid endosperm tissue was then squeezed through two layers of cheesecloth, and the resulting endosperm suspension was frozen and stored at $-80^{\circ} \mathrm{C}$ as previously described (Kowalczyk and Bandurski 1991).

\section{Chemicals}

1-O-IA-glucose was synthesized according to the method of Jakas et al. (1993). $\left[2{ }^{\prime}-{ }^{14} \mathrm{C}\right]$ IAA and D- $\left[{ }^{14} \mathrm{C}\right]$ glucose were from Amersham (UK). UDP-glucose, myo-inositol, melibiose, gentobiose, raffinose, stachyose, verbascose, saccharose, maltose were from Sigma (Germany).

Enzyme activity assays

\section{Qualitative assay}

A convenient qualitative assay, useful for localization of enzyme activity following column chromatography, was based upon separation of the reaction products by thin layer chromatography (TLC). Indole-3-acetic acid: glucosyltransferase (IAA-UGT) activity was determined in a total volume of $8 \mu \mathrm{l}$ containing $50 \mathrm{mM}$ HEPES-NaOH buffer, pH 7.4, $7.5 \mathrm{mM}$ UDPG, $4 \mathrm{mM}$ IAA, $2.5 \mathrm{mM} \mathrm{MgCl}_{2}$, and $3 \mu \mathrm{l}$ of enzyme. Incubation was for 30 or $60 \mathrm{~min}$ at $30^{\circ} \mathrm{C}$. The reaction was stopped by drying a $4 \mu \mathrm{l}$ aliquot on a Silica Gel 60 TLC plate. The reaction products were separated using solvent A consisting of ethyl acetate, methyl ethyl ketone, ethyl alcohol, water (5:3:1:1 by vol.). Indole compounds were visualized by dipping the plate in Ehmann's reagent, blotting, and drying at $100^{\circ} \mathrm{C}$ (Ehmann 1977).

Acyltransferase activities, transferring the IAA moiety from 1-O-IA-glucose to myo-inositol or to saccharides, were determined in a total volume of $8 \mu$ containing $1 \mathrm{mM}$ chemically synthesized $1-O$-IAGlc and $10 \mathrm{mM}$ myo-inositol (1-O-IAGlc-InosAc) or $10 \mathrm{mM}$ melibiose (1-O-IAGlc-SugAc) in $50 \mathrm{mM}$ HEPES-NaOH, pH 7.4. The reaction was started by the addition of $3 \mu \mathrm{l}$ of enzyme and after 30 or $60 \mathrm{~min}$ incubation at $30^{\circ} \mathrm{C}$ the reaction products were separated by TLC and visualized as described above. In the respective experiments, $10 \mathrm{mM}$ final concentrations of gentobiose, raffinose, stachyose, verbascose, maltose, and saccharose were used in place of melibiose.

\section{Quantitative assay}

Indole-3-acetic acid: glucosyltransferase (IAA-UGT) activity was assayed as described previously (Kowalczyk and Bandurski 1991). The reaction mixture $(100 \mu \mathrm{l})$ contained $50 \mathrm{mM}$ HEPES-NaOH buffer, $\mathrm{pH}$ 7.4, $7.5 \mathrm{mM}$ UDPG, $4 \mathrm{mM}$ IAA, and $0.05 \mu \mathrm{Ci}$ of $\left[2{ }^{\prime}{ }^{14} \mathrm{C}\right]$ IAA $\left(50 \mathrm{mCi} \mathrm{mmol}^{-1}\right), \quad 2.5 \mathrm{mM} \quad \mathrm{MgCl}_{2}$ and $0.25 \mathrm{mM}$ 2-mercaptoethanol. The reaction was started by the addition of $20 \mu \mathrm{l}$ of enzyme solution, and after $30 \mathrm{~min}$ incubation at $30^{\circ} \mathrm{C}$ was stopped by the addition of $0.5 \mathrm{ml}$ $50 \%(\mathrm{v} / \mathrm{v})$ 2-propanol. Then $0.5 \mathrm{ml}$ of the reaction mixture was transferred to a $2 \mathrm{ml}$ bed volume DEAE-Sephadex (acetate) column in 50\% (v/v) 2-propanol. The uncharged products (1-O-IA-glucose) not bound to the ion exchanger were eluted with $50 \%(\mathrm{v} / \mathrm{v}) 2$-propanol to make a total eluate volume of $5 \mathrm{ml} .1 \mathrm{ml}$ was used for radioactivity measurement in a Wallac 1409 liquid scintillation counter.

Acyltransferase activities (1-O-IAGlc-InosAc and 1-OIAGlc-SugAc) were determined by measurement of esterified $\left[2{ }^{\prime}{ }^{14} \mathrm{C}\right]$ IAA. $5 \mu \mathrm{l}$ of the reaction mixture contained: $2 \mathrm{mM}$ IAA and $0.015 \mu \mathrm{Ci}$ of $\left[2^{\prime}{ }^{14} \mathrm{C}\right]$ IAA $(50 \mathrm{mCi}$ $\mathrm{mmol}^{-1}$ ), $7.5 \mathrm{mM}$ UDPG, $2.5 \mathrm{mM} \mathrm{MgCl}{ }_{2}, 10 \mathrm{mM}$ myoinositol or $10 \mathrm{mM}$ melibiose (glucose, mannose, galactose, saccharose, maltose, gentobiose, raffinose, stachyose, verbascose) in $50 \mathrm{mM}$ HEPES-NaOH, pH 7.4 and glucosyltransferase (IAA-UGT) partially purified from maize endosperm (after IV step) (Kowalczyk and Bandurski 1991). The reaction was started by the addition of $3 \mu \mathrm{l}$ of 1-O-IAGlc-dependent acyltransferase, and after 30 or 60 min incubation at $30^{\circ} \mathrm{C}$ was stopped by drying a $4 \mu \mathrm{l}$ aliquot on a Silica Gel 60 TLC plate. UV absorbing regions identified as 1-O-IAGlc, IA-myo-inositol and IA-sugar esters were scraped individually from the plate and placed into a vial with $2 \mathrm{ml}$ scintillation fluid and then radioactivity was measured in a Wallac 1409 liquid scintillation counter. In some experiments, 1-O-IAGlc-SugAc activity was determined as IAA-UGT activity (quantitative assay), using $7.5 \mathrm{mM} \mathrm{UDPG}, 4 \mathrm{mM}$ IAA, and $0.05 \mu \mathrm{Ci}$ of $\left[2^{\prime}{ }^{14} \mathrm{C}\right]$ IAA $\left(50 \mathrm{mCi} \mathrm{mmol}^{-1}\right)$ without and in the presence of the appropriate sugar-acceptor in the reaction mixture.

In detection of 1-O-IAGlc-SugAc activity in immature and germinating maize and rice seeds, $8 \mu \mathrm{l}$ of the reaction mixture contains: $1 \mathrm{mM}$ chemically synthesized 1-O-IAglucose, $5 \mathrm{mM}$ glucose and $0.1 \mu \mathrm{Ci}$ of $\mathrm{D}-\left[{ }^{14} \mathrm{C}\right]$ glucose, $2.5 \mathrm{mM} \mathrm{MgCl} 2,0.25 \mathrm{mM}$ 2-mercaptoethanol, $50 \mathrm{mM}$ HEPES-NaOH buffer, $\mathrm{pH}, 7.4$. The reaction was started by the addition of $3 \mu \mathrm{l}$ of appropriate tissue homogenate, and after 30 and $60 \mathrm{~min}$ incubation at $30^{\circ} \mathrm{C}$ was stopped by drying a $4 \mu \mathrm{l}$ aliquot on a Silica Gel 60 TLC plate. IA- $\left[{ }^{14} \mathrm{C}\right]$ glucose esters were scraped individually from the plate and placed into a vial with $2 \mathrm{ml}$ scintillation fluid and then radioactivity was measured in a Wallac 1409 liquid scintillation counter.

Purification of 1-O-IAGlc-SugAc

\section{Fractionation with ammonium sulphate}

A $500 \mathrm{~g}$ portion of frozen endosperm was homogenized with $500 \mathrm{ml}$ of $25 \mathrm{mM}$ Tris- $\mathrm{HCl}$ buffer, $\mathrm{pH} 7.6$ containing $1 \mathrm{mM}$ 2-mercaptoethanol, using a Waring blender 
homogenizer. The homogenate, after adjusting the $\mathrm{pH}$ to 7.6, was centrifuged at $13,000 \mathrm{~g}$ for $30 \mathrm{~min}$. Solid ammonium sulphate was added slowly to the supernatant to obtain a $35 \%$ saturated solution $(1.4 \mathrm{M})$. The solution was gently stirred for $2 \mathrm{~h}$ and clarified by centrifugation at $13,000 \mathrm{~g}$ for $30 \mathrm{~min}$. The resultant supernatant was precipitated with ammonium sulphate at $67 \%$ of its saturation $(2.4 \mathrm{M})$. The solution was stirred for $4 \mathrm{~h}$ and then centrifuged at 22,000g for $1 \mathrm{~h}$. The pellet was dissolved in a minimum volume of $25 \mathrm{mM}$ Tris- $\mathrm{HCl}$ buffer, $\mathrm{pH} 7.6$ containing $1 \mathrm{mM}$ 2-mercaptoethanol and desalted by overnight dialysis against the same buffer.

\section{Anion-exchange chromatography on DEAE-Sephacel column}

The dialysate, after clarification, was applied to a DEAESephacel column $(2.5 \times 20 \mathrm{~cm})$ equilibrated with $25 \mathrm{mM}$ Tris-HCl buffer, pH 7.6 containing $1 \mathrm{mM}$ 2-mercaptoethanol (buffer A). The column was washed with the same buffer until the $A_{280}$ decreased to 0.1 , and finally the bound proteins were eluted with a linear gradient $(400 \mathrm{ml})$ of $0-250 \mathrm{mM} \mathrm{NaCl}$ in $25 \mathrm{mM}$ Tris-HCl buffer, $\mathrm{pH}$ 7.6. The flow rate was $0.9 \mathrm{ml} / \mathrm{min}$, and $7 \mathrm{ml}$ fractions were collected. The fractions containing the most activity of $1-O$-IAGlc-InosAc were pooled and concentrated. The fractions containing not completely separated IAA-UGT and $1-O$-IAGlc-SugAc were pooled together.

\section{Blue Sepharose chromatography}

The combined fractions containing IAA-UGT and 1-OIAGlc-SugAc activity were diluted with buffer $\mathrm{A}$, and applied to a $2.5 \mathrm{~cm} \times 28 \mathrm{~cm}$ Blue Sepharose column with a low dye loading at a flow rate of $0.8 \mathrm{ml} / \mathrm{min}$. The column was washed with equilibrating buffer (buffer A), and the adsorbed proteins were eluted with $0.5 \mathrm{M} \mathrm{NaCl}$ in buffer A. The fractions containing 1-O-IAGlc-SugAc were combined and concentrated to 3-5 ml by ultrafiltration with an Amicon Diaflo YM-10 filter. IAA-UGT eluted with $0.5 \mathrm{M}$ $\mathrm{NaCl}$ was pooled and precipitated with ammonium sulphate at $67 \%$ of its saturation.

\section{Concanavalin A-Sepharose affinity chromatography}

1-O-IAGlc-SugAc concentrate was applied to a column of ConA-Sepharose $(1 \times 3 \mathrm{~cm})$ equilibrated with $25 \mathrm{mM}$ Tris-HCl buffer, $\mathrm{pH}$ 7.6. The proteins not bound to ConASepharose were removed with buffer A. Weakly retained proteins were eluted with buffer A containing $0.2 \mathrm{M} \mathrm{NaCl}$, and the remaining proteins with buffer containing $5 \%(\mathrm{w} / \mathrm{v})$ methyl $\alpha$-D-mannopyranoside. Fractions containing $1-O$ IAGlc-SugAc activity were pooled and concentrated.
Adsorption chromatography on a hydroxylapatite (Bio-Gel HTP) column

The concentrated fractions from ConA-Sepharose were applied very slowly to a hydroxylapatite column $(2.0 \times$ $2.5 \mathrm{~cm}$ ) equilibrated with $25 \mathrm{mM}$ Tris- $\mathrm{HCl}$ buffer, $\mathrm{pH}$ 7.6. Weakly retained proteins were removed by washing a column with the same buffer and the adsorbed proteins were eluted with $5 \mathrm{mM}$ phosphate (K) buffer, $\mathrm{pH} 7.4$, and next with 10 and $20 \mathrm{mM}$ phosphate (K) buffer. The active fractions eluted with $5 \mathrm{mM} \mathrm{mM}$ phosphate (K) were pooled and concentrated by ultrafiltration using an Amicon Diaflo YM-10 filter.

\section{Preparative gel electrophoresis}

The concentrated active fractions were subjected to semipreparative PAGE in $8 \%(\mathrm{w} / \mathrm{v})$ resolving gel according to the method of Ogita and Markert (1979). Proteins were resolved in gel of $15 \times 15 \times 1 \mathrm{~mm}$ using a vertical slab electrophoresis apparatus (BRL model V-16). The samples were applied to a $45 \mathrm{~mm}$ wide wheel, and after electrophoresis, the gel was cut into three strips according to the direction of resolving. The outside strips were stained briefly with Coomassie Brilliant Blue G-250 in 3.5\% (v/v) perchloric acid and 20\% (v/v) methanol (Blakesly and Boezi 1977) and then washed with distilled water. The appropriate $3 \mathrm{~mm}$ wide segment of gel from the middle strip (not stained) was excised on the basis of the position of protein bands stained on the outside strips. This segment of gel was transferred into a dialyze tube and placed in a horizontal electrophoresis apparatus. The proteins were electroeluted with the standard electrode buffer at $20 \mathrm{~mA}$ for $2-3 \mathrm{~h}$.

\section{SDS-PAGE}

Electrophoresis under non-denaturing conditions and SDSPAGE was performed according to the method of Ogita and Markert (1979) in a Mini Protean II electrophoresis cell (Bio-Rad) using 8\% (w/v) resolving gel for native proteins and $12 \%(\mathrm{w} / \mathrm{v})$ gel for denatured proteins. The proteins used as molecular mass standards in SDS-PAGE were a $10 \mathrm{kDa}$ Protein Ladder (Gibco). Native proteins were stained with Coomassie Brilliant Blue G-250 in 3.5\% (v/v) perchloric acid and 20\% (v/v) methanol, and SDS denatured proteins were visualized by silver staining (Harlow and Lane 1988).

\section{Protein determination}

Protein was determined photometrically at $280 \mathrm{~nm}$ or by the Bradford method (Bradford 1976) using $\gamma$-globulin as a standard. 


\section{Results and discussion}

Detection of 1-O-IAGlc-SugAc activity in immature corn endosperm

Within the group of conjugated IAA, there is a unique class of ester conjugates where IAA is attached to myo-inositol, myo-inositol glycosides and to cellulosic glucans. Most of our knowledge on IAA ester conjugation has come from studies on maize done by Bandurski and co-workers (Bandurski et al. 1995; Slovin et al. 1999). The synthesis of 1-O-IAGlc, followed by transacylation to myo-inositol represents two potential regulatory steps for the control of IAA concentration by converting hormonally active free IAA into growth-inactive IAA esters. However, it is notable that 1 - $O$-IAGlc-dependent myo-inositol acyltransferase (1-O-IAGlc-InosAc) is not the only enzyme using 1-O-IAGlc as a donor of the acyl group. In vitro experiments indicated that in maize seedlings and immature corn endosperm, the disproportionation of two 1-O-IAGlc molecules to generate di-O-(indole-3-acetyl)-D-glucose and the transfer of IAA moiety to some oligosaccharides from the raffinose family occur (Szmidt-Jaworska et al. 1997; Leźnicki and Bandurski 2001). Furthermore, during the course of our previous studies, the transfer of IAA moiety from 1-O-IAGlc to high molecular acceptors was observed (Jakubowska and Kowalczyk 2004). On the other hand, the transfer of IAA moiety from IAInos to a monosaccharide (glucose, galactose, and mannose) as acceptor was demonstrated as well (Kowalczyk et al. 2003). In spite of the work reported thus far, many aspects of the IAA-ester

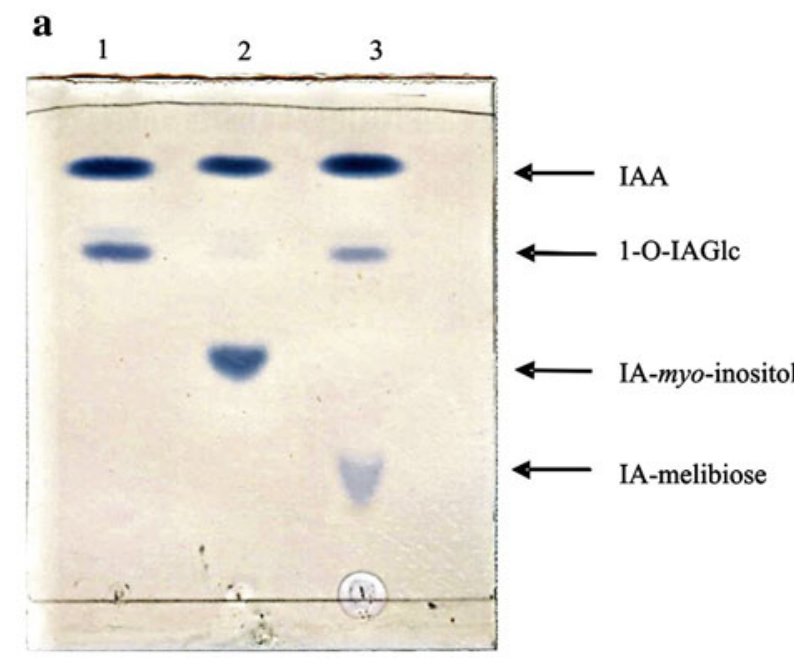

Fig. 1 TLC analysis of in vitro enzymatic synthesis of IAA and IBA conjugates by immature maize endosperm. The reaction mixture $(8 \mu \mathrm{l})$ contained $50 \mathrm{mM}$ HEPES-NaOH pH 7.4, $4 \mathrm{mM}$ indole-3acetic acid (a) or $4 \mathrm{mM}$ indole-3-butyric acid (b), $7.5 \mathrm{mM}$ UDPG, $2.5 \mathrm{mM} \mathrm{MgCl}_{2}(\mathbf{a}$, lane $1 ; \mathbf{b}$, lane 1) and $10 \mathrm{mM}$ myo-inositol (a, lane conjugates metabolism require further investigation. In the first place, it is essential to have prior knowledge of all acyltransferases synthesizing IAA-conjugates in 1-O-IAGlc-dependent transacylation reactions. Until now, there has been no particular knowledge about the enzyme synthesizing IA-sugar conjugates other than 1-O-IAGlc.

Recently, the elementary qualitative assay showed that in the reaction mixture containing IAA, UDP-glucose, myo-inositol or melibiose, and homogenate of liquid maize endosperm, the synthesis of 1-O-IAGlc, and IA-myo-inositol or IA-melibiose occurs (Starzyńska and Kowalczyk 2007). In this study, it was evidenced that only 1-O-IAGlc is synthesized when an acceptor of IAA-moiety is absent (Fig. 1a, lane 1), but IA-myo-inositol is almost the sole visible product when the reaction mixture contains myo-inositol (Fig. 1a, lane 2). Using melibiose, in place of myo-inositol (Fig. 1a, lane 3), the synthesis of IA-melibiose was observed, and residual 1-O-IAGlc was visible as well. Apart from this, the data shown in (Fig. 1b) demonstrate that in the presence of indole-3-butyric acid (IBA) in the reaction mixture, instead of IAA, only a negligible amount of 1-O-(indole-3-butyryl)- $\beta$-D-glucose (1-O-IBGlc) is synthesized after $30 \mathrm{~min}$ incubation without (Fig. 1b, lane 1), and in the presence of an acyl acceptor (Fig. 1b, lane 2 and 3). Then, the maize IAA-UGT exhibits minimal enzymatic activity with IBA, contrary to the recombinant IAA-UGT of Arabidopsis (UGT84B2) that uses indole butyric acid and indole propionic acid (IPA) comparable with IAA (Jackson et al. 2001).

In the previous study, the substrate specificity of 1-OIAGlc-dependent myo-inositol acyltransferase (1-O-IAGlc-

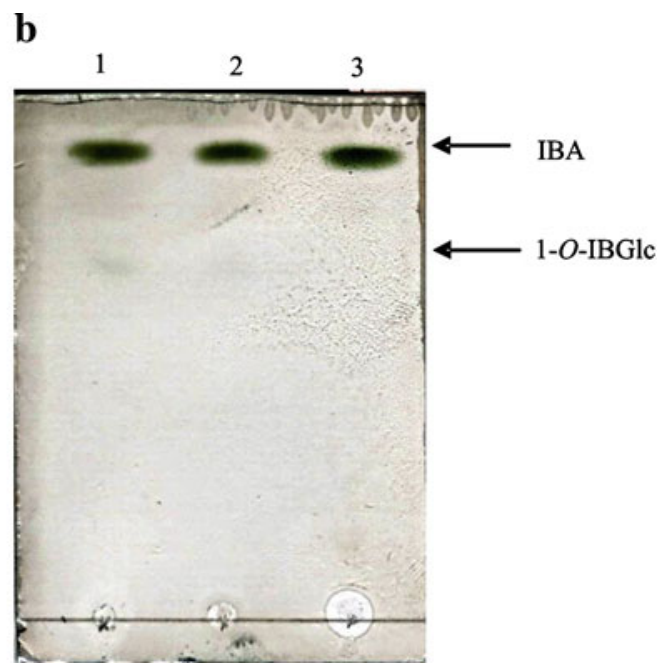

2; b, lane 2) or $10 \mathrm{mM}$ melibiose (a, lane 3; b, lane 3) and $3 \mu \mathrm{l}$ of whole tissue homogenate of maize endosperm. The samples were incubated for $30 \mathrm{~min}$ at $30^{\circ} \mathrm{C}$ and the reaction products were analyzed by TLC. Indole compounds were visualized by Ehmann's reagent as described in "Materials and methods" 

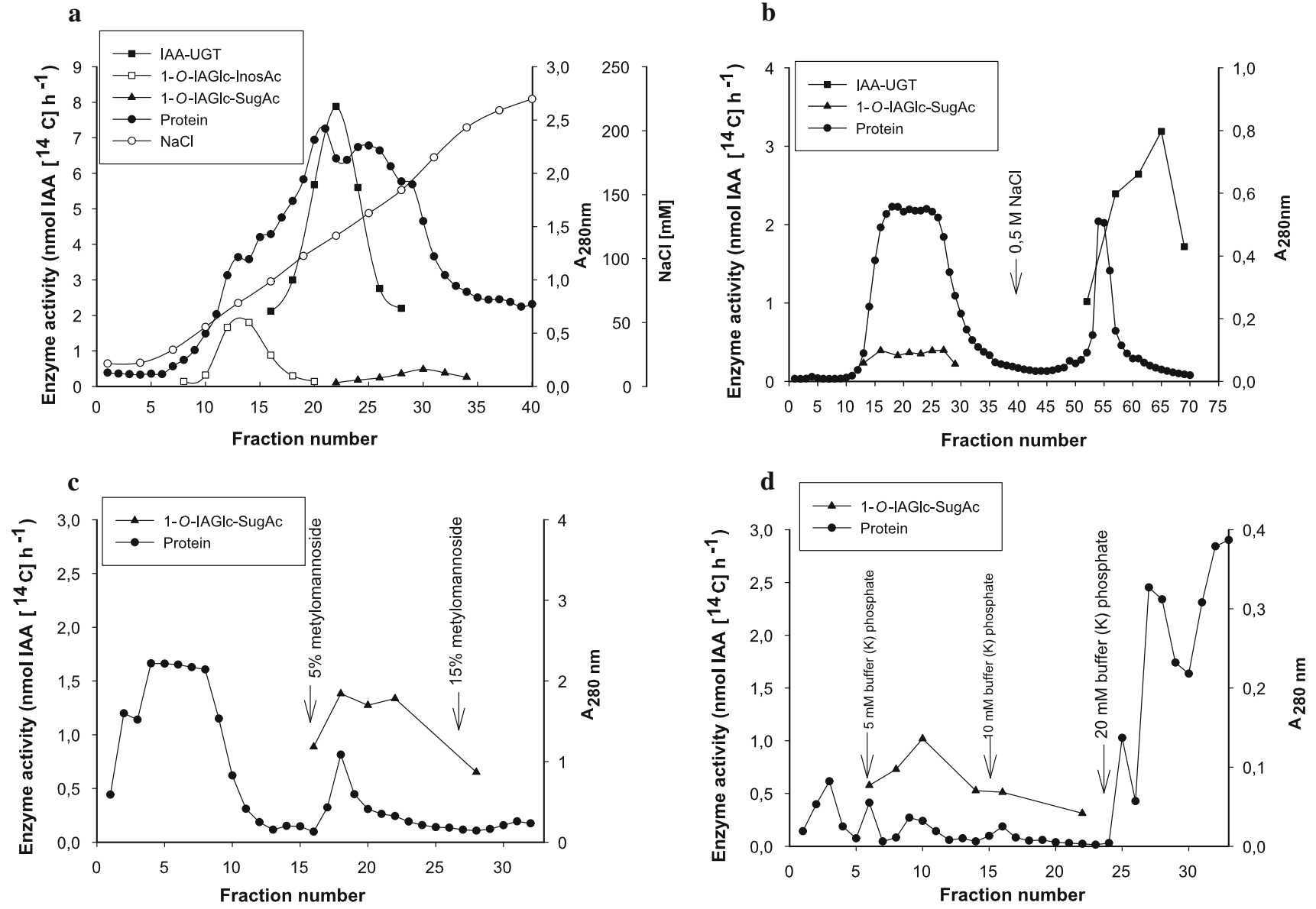

Fig. 2 Purification of 1-O-IAGlc-dependent sugar acyltransferase (1$O$-IAGlc-SugAc). a elution profile of 1- $O$-IAGlc-SugAc, 1- $O$-IAGlcInosAc and IAA-UGT activity from DEAE-Sephacel columnfractions were eluted using a linear gradient of $0-250 \mathrm{mM} \mathrm{NaCl}$ in the equilibrating buffer; $\mathbf{b}$ elution profile of 1-O-IAGlc-SugAc and IAA-UGT activity from a Blue Sepharose column-1-O-IAGlcSugAc activity was eluted with equilibrating buffer, remaining proteins containing IAA-UGT activity were eluted with $0.5 \mathrm{M} \mathrm{NaCl}$

InosAc) was tested only toward several alcohols, but not toward sugars (Kęsy and Bandurski 1990), which is why the separation of 1-O-IAGlc-SugAc from 1-O-IAGlc-InosAc and from other potential 1-O-IAGlc-dependent acyltransferases has a major significance. In our preliminary experiments, the several sugar acceptors of IAA moiety were tested, however, in all qualitative assays and during purification of 1-O-IAGlc-SugAc, a melibiose was used as a sole acceptor. Effectively synthesized IA-melibiose is readily separable from 1-O-IAGlc, therefore TLC plates in the short dimension permit dozens of simultaneous qualitative assays.

\section{1-O-IAGlc-SugAc purification}

1-O-IAGlc-SugAc was purified using fractionation by ammonium sulphate, anion exchange chromatography on

in equilibrating buffer; c affinity chromatography of 1-O-IAGlcSugAc on a ConA-Sepharose column-1-O-IAGlc-SugAc bound to the ConA-Sepharose gel was eluted with $5 \%(\mathrm{w} / \mathrm{v})$ methyl mannopyranoside; d elution profile of 1-O-IAGlc-SugAc from a hydroxylapatite Bio-Gel HTP column-enzyme activity was eluted with $5 \mathrm{mM}$ (K) phosphate buffer, $\mathrm{pH} 7.4$, and the adsorbed proteins were eluted with 10 and $20 \mathrm{mM}(\mathrm{K})$ phosphate buffer, $\mathrm{pH} 7.4$

DEAE-Sephacel, ConA-Sepharose affinity chromatography, adsorption chromatography on hydroxylapatite and preparative gel electrophoresis. Initial fractionation of the homogenate with ammonium sulphate allowed the removal of a large quantity of contaminating proteins. 1-O-IAGlcSugAc was precipitated between 36 and $67 \%$ of saturation. A single peak of 1-O-IAGlc-SugAc activity was revealed during anion-exchange chromatography (Fig. 2a) shows that 1-O-IAGlc-SugAc was eluted with $175 \mathrm{mM} \mathrm{NaCl}$, whereas 1-O-IAGlc-InosAc already with $80 \mathrm{mM} \mathrm{NaCl}$. 1-O-IAGlc-SugAc and IAA-UGT partially co-elute, therefore the active fractions were pooled together and applied to Blue Sepharose column with a low dye loading. 1-O-IAGlc-SugAc was eluted with $25 \mathrm{mM}$ Tris- $\mathrm{HCl}, \mathrm{pH}$ 7.6 (equilibrating buffer; buffer A), while the remaining proteins containing IAA-UGT were eluted with $0.5 \mathrm{M}$ $\mathrm{NaCl}$ in equilibrating buffer, as shown in (Fig. 2b). Affinity 
chromatography on ConA-Sepharose was a very effective step in the purification procedure of $1-O$-IAGlc-SugAc. It allowed the removal of the most contaminating proteins. As shown in (Fig. 2c), a single peak of 1-O-IAGlc-SugAc eluted with $5 \%$ methyl $\alpha$-D-mannopyranoside was observed. The fractions containing most of the 1-O-IAGlcSugAc activity (Nos. 15-28) were combined and applied to a hydroxylapatite column. Weakly retained proteins were removed by washing the column with buffer $\mathrm{A}$, and the adsorbed proteins were eluted with $5 \mathrm{mM}$ phosphate (K) buffer, $\mathrm{pH} 7.4$, and next with $10 \mathrm{mM}$ and $20 \mathrm{mM}$ phosphate $(\mathrm{K})$ buffer. The results of the adsorption chromatography are shown in (Fig. 2d). Most of the 1-O-IAGlc-SugAc was eluted with $5 \mathrm{mM}$ phosphate $(\mathrm{K})$ buffer. The preparation of 1-O-IAGlc-SugAc was subjected to preparative PAGE in $8 \%(\mathrm{w} / \mathrm{v})$ resolving gel as described in "Materials and methods". It was known from the preliminary studies that $1-O$-IAGlc-SugAc preparation after ConA-Sepharose chromatography revealed the presence of the protein bands at $R_{\mathrm{f}} 0.67$ containing enzyme activity (Starzyńska and Kowalczyk 2007). After preparative PAGE, the protein band was cut out from the plate and eluted from the gels. Analytical non-denaturing PAGE used to verify effectiveness of the purification procedure demonstrates only one protein band in the preparation ( $R_{\mathrm{f}}$ 0.67; Fig. 3a, lane 1 and 2 ). The excised and eluted protein band was analyzed by SDS-PAGE. The enzyme preparation at this stage of purification yields three
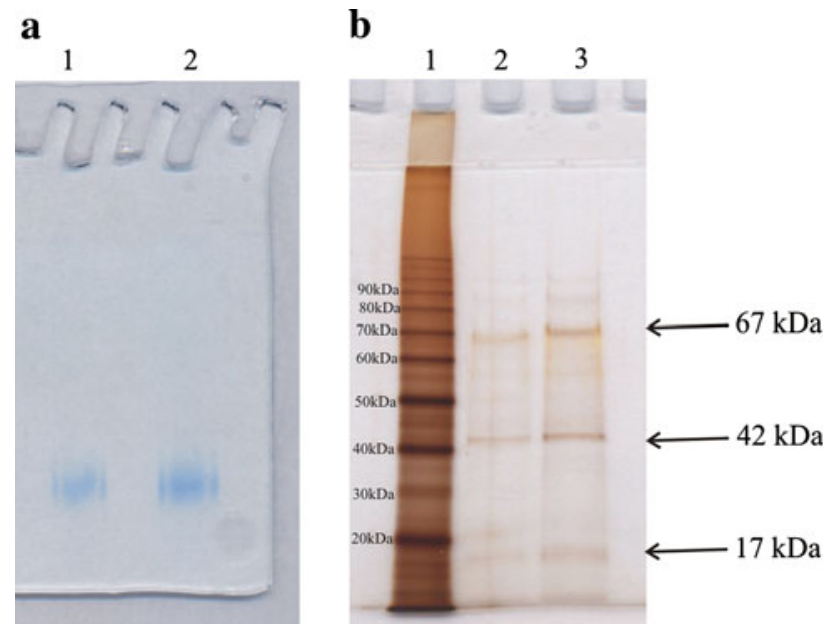

Fig. 3 PAGE and SDS-PAGE analysis of the protein band eluted after preparative electrophoresis. a The protein band at $R_{\mathrm{f}} 0.67$ was excised, eluted from the gel and subjected to non-denaturing PAGE in $8 \%(\mathrm{w} / \mathrm{v})$ resolving gel (a, lanes 1 and 2$)$. The gel was stained with Coomassie Blue; b SDS-PAGE analysis excised a protein band at $R_{\mathrm{f}}$ 0.67 . Electrophoresis was performed using $12 \%(\mathrm{w} / \mathrm{v})$ polyacrylamide gel and polypeptides were visualized by silver staining. Lane 1, molecular mass standards; lanes 2 and 3, polypeptides in 1-O-IAGlcSugAc preparation obtained after purification. The polypeptides of 42 and $17 \mathrm{kDa}$ are products of $1-O$-IAGlc-SugAc processing intensive bands $(67,42$ and $17 \mathrm{kDa})$. We assume that polypeptides of $42 \mathrm{kDa}$, and $17 \mathrm{kDa}$ represent 1 - $O$-IAGluSugAc, whilst a band of $67 \mathrm{kDa}$ may be due to a high concentration of 2-mercaptoethanol in SDS gels (Bollag and Edelstein 1991), because the same band of $67 \mathrm{kDa}$ yields sample buffer separately loaded on gel (not shown). Presently, the increasing evidence indicate that several 1 - $O$-acyl- $\beta$-D-glucose-dependent acyltransferases metabolizing secondary metabolites reveal posttranslational processing which results, in the endoproteolytic cleavage of the mature proteins, in two subunits, a large one, and a smaller of 17-24 kDa (Li and Steffens 2000; Mugford et al. 2009; Stehle et al. 2009).

1-O-IAGlc-SugAc may be prepared from fresh or frozen kernels, however it is subject to large unexplained losses of activity during some preparatory steps. Described purification procedure entails large losses of activity (above $98 \%$ ), but it proved to be useful in preparing purified protein for microsequencing. A polypeptide of $42 \mathrm{kDa}$, separated on SDS-PAGE and electroblotted on PVDF membrane, was used for tryptic peptide sequencing (results was not shown), and the data obtained are currently utilized to select a cDNA clone.

\section{Substrate specificity of 1-O-IAGlc-SugAc}

Assays were performed to test the possibility of a transfer reaction of the IAA residue from 1-O-IAGlc to a hydroxyl group of several mono-, and disaccharides, as well as some oligosaccharides from the raffinose family. The reaction was conducted using a highly purified 1-O-IAGlu-SugAc preparation (after chromatography on hydroxylapatite). The reaction products were IA-saccharide esters which were separated on a TLC plate as described in "Materials and methods". As can be seen in (Table 1), highly purified 1-O-IAGlu-SugAc effectively transfers IAA moiety from 1-O-IAGlc to mannose and glucose, and only somewhat more slowly to galactose. Moreover, the results evidence that 1-O-IAGlu-SugAc uses melibiose as the IAA acceptor (52\% of the activity of mannose) but does not use saccharose and maltose. Gentobiose and raffinose showed $21-22 \%$ of the activity of mannose, but stachyose and verbascose only $8 \%$ of the reactivity of mannose. Melibiose (6- $O-\alpha$-D-galactopyranosyl-D-glucopyranose) is a much better IAA acceptor than raffinose, stachyose and verbascose-the sugars that also possess $O-\alpha-1 \rightarrow 6$ glycosidic linkage at the non reducing end. Gentobiose, a disaccharide containing a $6-O-\beta$-glycosidic bond, is a similarly effective acceptor as raffinose possessing 6-O- $\alpha$-glycosidic linkage. At any rate, it is notable, that all three monosaccharides tested are the best acceptors of IAA moiety transferred from 1- $O$-IAGlc by a novel acyltransferase. All synthesized ester linked IA-sugars are respectively stable 
Table 1 Substrate specificity of 1-O-IAGlc-dependent sugar acyltransferase

\begin{tabular}{|c|c|}
\hline Substrate tested & $\begin{array}{l}\text { Enzyme activity (nmol }\left[{ }^{14} \mathrm{C}\right] \\
\text { IA-Sug } \mathrm{h}^{-1} 3 \mu \mathrm{l}^{-1} \text { enzyme) }\end{array}$ \\
\hline Mannose & $1.13(100 \%)$ \\
\hline Glucose & $1.12(99.2 \%)$ \\
\hline Galactose & $0.89(79.2 \%)$ \\
\hline Melibiose (6-O- $\alpha$-D-galactopyranosyl-D-glucopyranose) & $0.58(51.7 \%)$ \\
\hline Gentobiose (6- $O$ - $\beta$-D-glucopyranosyl-D-glucopyranose) & $0.25(22.3 \%)$ \\
\hline Raffinose $(6-O-\alpha$-D-galactopyranosyl $(1 \rightarrow 6)$ - $\alpha$-D-glucopyranosyl-( $1 \rightarrow 2)$ - $\beta$-D-fructofuranose $)$ & $0.24(21.3 \%)$ \\
\hline $\begin{array}{l}\text { Stachyose }(6-O-\alpha \text {-D-galactopyranosyl- }(1 \rightarrow 6)-\alpha \text {-D-galactopyranosyl- }(1 \rightarrow 6) \text { - } \alpha \text {-D-glucopyranosyl- } \\
\quad(1 \rightarrow 2)-\beta \text {-D-fructofuranose })\end{array}$ & $0.10(8.88 \%)$ \\
\hline $\begin{array}{l}\text { Verbascose }(6-O \text { - } \alpha \text {-D-galactopyranosyl- }(1 \rightarrow 6) \text { - } \alpha \text {-D-galactopyranosyl- }(1 \rightarrow 6)-\alpha \text { - } \\
\text { D-galactopyranosyl- }(1 \rightarrow 6)-\alpha \text {-D-glucopyranosyl }(1 \rightarrow 2)-\beta \text {-D-fructofuranose })\end{array}$ & $0.09(8.34 \%)$ \\
\hline Saccharose (1- $O$ - $\alpha$-D-glucopyranosyl- $\beta$-D-fructofuranose) & Not detected \\
\hline Maltose (4-O- $\alpha$-D-glucopyranosyl-D-glucopyranose) & Not detected \\
\hline
\end{tabular}

Table 2 The activity of 1-O-IAGlc-dependent glucose acyltransferase in different tissues of germinating corn and rice seeds

\begin{tabular}{llr}
\hline Plant & Tissue & $\begin{array}{l}\text { Enzyme activity (nmol IA }\left[{ }^{14} \mathrm{C}\right] \\
\left.\mathrm{glucose}^{-1} \mathrm{~g}^{-1} \mathrm{FW}\right)\end{array}$ \\
\hline Zea mays & Embryo from mature seeds, 24 h after imbibitions & $123.1 \pm 22.9$ \\
& Scutellum from mature seeds, 24 h after imbibition & $89.5 \pm 8.0$ \\
& Endosperm from mature seeds, 24 h after imbibitions & $98.2 \pm 9.5$ \\
Oryza sativa & Liquid endosperm & $188.9 \pm 26$ \\
\end{tabular}

All values are mean $\pm \mathrm{SD}(n=3)$

$F W$ fresh weight

conjugates, as distinct from 1-O-IAGlc, thereby their role appears to be a storing of free IAA in maturating seeds and reusing it for the early stages of seed germination and development.

Detection of 1-O-IAGlc-GlcAc in immature and germinating maize and rice seeds

Quantitative assays of 1-O-IAGlc-GlcAc activity, based on the measurement of IA- $\left[{ }^{14} \mathrm{C}\right]$-glucose esters produced from chemically synthesized $1-O$-IAGlc and $\left[{ }^{14} \mathrm{C}\right]$-glucose as an acceptor of IAA moiety, were used for testing of acyltransferase activity in immature and germinating maize and rice seeds. The reaction was conducted using a homogenate of liquid corn endosperm, and homogenates of developed embryo, scutellum and endosperm of corn seeds, as well a homogenate of mature rice seeds, $24 \mathrm{~h}$ after the seeds imbibition. Table 2 shows activities (on a fresh weight basis) of the 1-O-IAGlc-GlcAc in analyzed tissues. The highest enzymatic activity was found in germinating rice seeds $\left(235 \pm 15 \mathrm{nmol}\right.$ of IA- $\left[{ }^{14} \mathrm{C}\right]$ Glc-esters/h per $\mathrm{g}$ fresh wt.) which was comparable with $1-O$-IAGlc-GlcAc activity present in liquid endosperm of maize $(188.9 \pm 26 \mathrm{nmol}$
IA- $\left[{ }^{14} \mathrm{C}\right]$ Glc-esters/h per $\mathrm{g}$ fresh wt.). Lower enzymatic activity was found in homogenates of germinating maize seeds (embryo, scutellum and endosperm) (Table 2).

The disproportionation of two 1-O-IAGlc molecules

Years ago, Li and Steffens (2000) reported the isolation of cDNA encoding the acyltransferase responsible for the formation of diacyl glucose, an intermediate in the biosynthesis of glucose polyesters. In this case, 1-O- $\beta$ isobutyryl glucose donor is utilized in the transfer of the isobutyryl moiety to another $1-O-\beta$-isobutyryl glucose molecule, forming 1,2-di- $O$-diisobutyryl- $\beta$-glucose. It is of interest that a similar disproportionation reaction was found in extracts of maize seedlings which produce di- $O$ (indole-3-acetyl)-D-glucose from 1-O-IAGlc (Szmidt-Jaworska et al. 1997). On the basis of these data we have tested a highly purified 1-O-IAGlc-SugAc preparation (after chromatography on hydroxylapatite) for disproportionation of 1-O-IAGlc. The reaction was performed in a standard reaction mixture containing $1 \mathrm{mM}$ chemically synthesized 1-O-IAGlc, $10 \mathrm{mM}$ melibiose and $50 \mathrm{mM}$ buffer HEPES$\mathrm{NaOH}, \mathrm{pH} 6.45$ to 7.6. The data shown in Fig. 4 evidence 


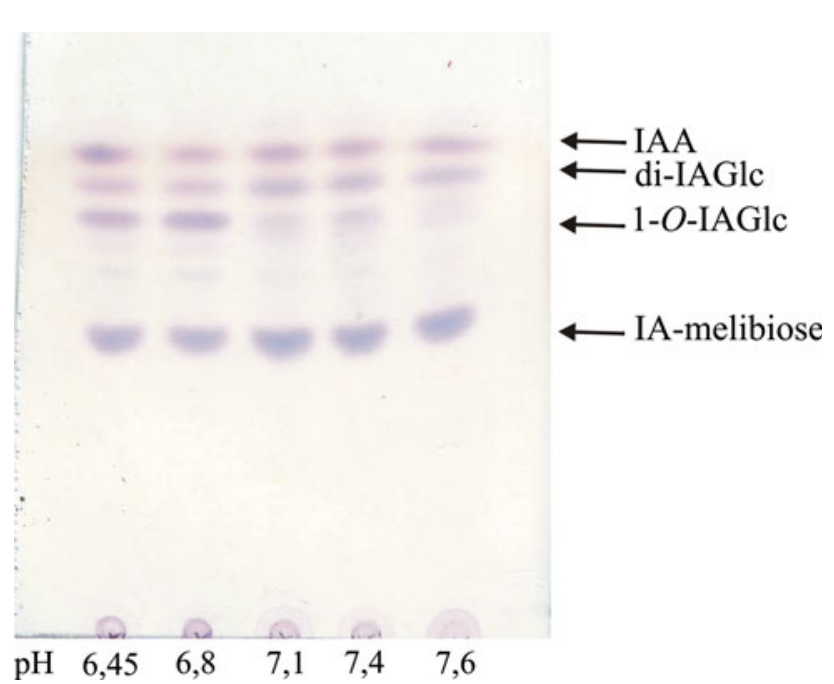

Fig. 4 Transfer of IAA moiety at different $\mathrm{pH}$ value from chemically synthesized 1-O-IAGlc to melibiose, to water (1-O-IAGlc hydrolysis) and to second molecule of $1-O-\mathrm{IAGlc}$ (disproportionation reaction) by highly purified 1 - $O$-IAGlc-SugAc

that the enzyme produces not only IA-melibiose, but also free IAA, as well as an unknown new product of similar $R_{\mathrm{f}}$ value to the previously identified di-IA-glucose (SzmidtJaworska et al. 1997). Although the enzyme activity was detectable in a wide $\mathrm{pH}$ range from 6.4 to 7.6, clearly more intensive metabolism of 1-O-IAGlc was observed at a $\mathrm{pH}$ above 7.1 (Fig. 4).

It is noteworthy that $1-O$-sinapoyl- $\beta$-glucose-dependent L-malate sinapoyltransferase (SMT) from Arabidopsis similarly exhibits besides its primary sinapoylation of L-malate, minor disproportionation and hydrolytic activities, producing 1,2-di- $O$-sinapoyl- $\beta$-glucose and sinapic acid, respectively (Stehle et al. 2008). SMT and isobutyrylGlc acyltransferase are members of a large family of serine carboxypeptidase-like (SCPL) proteins (Stehle et al. 2008, 2009). Several enzymes from this family use 1- $O$ - $\beta$-acyl glucose as acyl donors instead of coenzyme A thioesters. The synthesis of isobutyryl-glucose esters in Lycopersicon pennellii, and formation a complex pattern of sinapate esters composed of malate, choline, glucose, gentobiose, kaempferol glycoside in Arabidopsis and some other members of the Brassicaceae are catalyzed by the acyltransferases that use 1-O-AcylGlc as acyl donors (Baumert et al. 2005; Stehle et al. 2008, 2009). SCPL family acyltransferases also includes recently cloned in our laboratory 1-O-IAGlc-InosAc (submitted for publication), and presumably, a new-revealed 1-O-IAGlc-SugAc, as well.

The biochemical role of 1-O-IAGlc-SugAc

As regards the biochemical role of 1-O-IAGlc-SugAc, it seems that the produced stable esters of IAA and glucose (presumably 4-O- and 6-O-IAGlc) (Kowalczyk and
Bandurski 1990) or some other monosaccharides are the real storage forms of IAA. Both 4-O- and 6-O-IAGlc glucose esters are the most stable forms of the IAGlc conjugated hormone (Kowalczyk and Bandurski 1990), and both esters cause the stimulation of oat coleoptile growth in elongation tests (Jakubowska et al. 1993). Moreover, it is of importance that the specific enzyme hydrolyzing these ester conjugates was found in immature kernels of corn (Jakubowska and Kowalczyk 2005). Partially purified hydrolase exhibits no activity when tested with 1-O-IAGlc and IAInos, but among a range of ester conjugates tested as the substrate, only 6-O (4-O)-IA-glucose and IBA-glucose isomers are effectively hydrolyzed by this enzyme. The results of these experiments may confirm the hypothesis that hydrolysis of ester-linked IAAsugar conjugates in maize and rice is a part of the mechanism regulating the free auxin levels; especially for the early stages of plant growth and development.

On the other hand, quantitative analysis of IAA metabolites in Arabidopsis seedlings showed that free IAA and IAGlc are present in equal amounts as low as 40-70 pmol/g fresh wt., and a 22-47 times higher level of OxIAGlc (1,500-1,900 pmol/g fresh wt.) has been demonstrated (Kai et al. 2007). These amounts of OxIAGlc are far above the level of IAA-amino acid conjugates (IAAsp, IAGlu) as well. Since IAA-UGT exhibited no activity toward OxIAA (Jackson et al. 2001), OxIAGlc is therefore most likely produced by the oxidation of IAGlc esters. It is generally understood that OxIAGlc is inactive as an auxin and is unlikely to be reversibly converted to IAA; therefore, the synthesis of IAGlc esters, followed by their oxidation to OxIAGlc, may also play a catabolic role. It is of interest that the amide conjugates with Asp, Glu, Ala, Gly, Val, and Leu, which have been found in a variety of plants, similarly play a different role (Ludwig-Müller 2011; Tam et al. 2000). It is assumed that conjugates with alanine and leucine represent reversible, inactive storage forms, whilst IA-aspartate and IA-glutamate are the catabolites of IAA (Ludwig-Müller 2011).

Obviously, it should no be excluded that 1-O-IAGlcSugAc is involved in the formation of some high molecular weight IAA-conjugates e.g. $1 \rightarrow 4$ cellulosic glucans or glycoproteins, quantitatively composed the largest pool of ester linked IAA-conjugates in corn seed (Bandurski et al. 1995; Slovin et al. 1999).

At any rate, there is considerable evidence that IAA conjugation with several sugars represents one qualitatively and quantitatively important aspect of IAA levels in plant cells, and that these IAA conjugates may represent temporary storage forms from which free active hormone can be released via hydrolysis, but other IA-sugar conjugates may represent a regulatory shunt in the face of increased auxin supply. 
Open Access This article is distributed under the terms of the Creative Commons Attribution Noncommercial License which permits any noncommercial use, distribution, and reproduction in any medium, provided the original author(s) and source are credited.

\section{References}

Bandurski RS, Cohen JD, Slovin JP, Reinecke DM (1995) Auxin biosynthesis and metabolism. In: Davies PJ (ed) Plant hormones: physiology, biochemistry and molecular biology. Kluwer Academic Publishers, Dordrecht, pp 39-65

Baumert A, Milkowski J, Schmidt M, Nimtz M, Wray V, Strack D (2005) Formation of a complex pattern of sinapate esters in Brassica napus seeds, catalyzed by enzymes of a serine carboxypeptidase-like acyltransferase family? Phytochemistry 66:1334-1345

Bialek K, Cohen JD (1989) Free and conjugated indole-3-acetic acid in developing bean seeds. Plant Physiol 91:775-779

Blakesly RW, Boezi JA (1977) A new staining technique for proteins in polyacrylamide gels using Coomassie Brilliant Blue G250. Anal Biochem 82:580-582

Bollag DM, Edelstein SJ (1991) Protein methods. Wiley, Inc, Publication

Bradford MM (1976) A rapid and sensitive method for the quantitation of microgram quantities of protein utilizing the principle of protein-dye binding. Anal Biochem 72:248-254

Caboche M, Aranda G, Poll AM, Huet J-C, Leguay J-J (1984) Auxin conjugation by tobacco mesophyll protoplasts. Correlations between auxin cytotoxicity under low density growth conditions and induction of conjugation processes at high density. Plant Physiol 75:54-59

Catalá C, Östin A, Chamarro J, Sandberg G, Crozier A (1992) Metabolism of indole-3-acetic acid by pericarp discs from immature and mature tomato (Lycopersicon esculentum Mill.). Plant Physiol 100:1457-1463

Chisnell JR (1984) Myo-inositol esters of indole-3-acetic acid are endogenous components of Zea mays L. shoot tissue. Plant Physiol 74:278-283

Corcuera LJ, Bandurski RS (1982) Biosynthesis of indol-3-yl-acetylmyo-inositol arabinoside in kernels of Zea mays L. Plant Physiol 70:1664-1666

Corcuera LJ, Michalczuk L, Bandurski RS (1982) Enzymic synthesis of indol-3-ylacetyl-myo-inositol galactoside. Biochem J 207:283-290

Delbarre A, Muller P, Imhoff V, Morgat J-L, Barbier-Brygoo H (1994) Uptake, accumulation and metabolism of auxins in tobacco leaf protoplasts. Planta 195:159-167

Ehmann A (1974) Identification of 2-O-(indole-3-acetyl)-D-glucopyranose, 4- $O$-(indole-3-acetyl)-D-glucopyranose and 6- $O$-(indole3-acetyl)-D-glucopyranose from kernels of Zea mays by gasliquid chromatography-mass spectrometry. Carbohydr Res 34:99-114

Ehmann A (1977) The Van Urk-Salkowski reagent-a sensitive and specific chromogenic reagent for silica gel thin-layer chromatographic detection and identification of indole derivatives. J Chromatogr 132:267-276

Epstein E, Cohen JD, Bandurski RS (1980) Concentration and metabolic turnover of indoles in germinating kernels of Zea mays L. Physiol Plant 65:415-421

Ganguly T, Ganguly SN, Sircar PK, Sircar SM (1974) Rhamnose bound indole-3-acetic acid in the floral parts of Peltophorum ferrugineum. Physiol Plant 31:330-332

Hall PJ (1980) Indole-3-acetyl-myo-inositol in kernels of Oryza sativa. Phytochemistry 19:2121-2123
Harlow E, Lane D (1988) Antibodies. A laboratory manual. Cold Spring Harbor Laboratory Press, New York

Iyer M, Slovin JP, Epstein E, Cohen JD (2005) Transgenic tomato plants with a modified ability to synthesize indole-3-acetyl- $\beta-1$ $O$-D-glucose. J Plant Growth Regul 24:142-152

Jackson RG, Lim E-K, Li Y, Kowalczyk M, Sandberg G, Hoggett J, Ashford DA, Bowles DJ (2001) Identification and biochemical characterization of an Arabidopsis indole-3-acetic acid glucosyltransferase. J Biol Chem 276:4350-4356

Jackson RG, Kowalczyk M, Li Y, Higgins G, Ross J, Sandberg G, Bowles DJ (2002) Over-expression of an Arabidopsis gene encoding a glucosyltransferase of indole-3-acetic acid: phenotypic characterization of transgenic lines. Plant J 32:573-583

Jakas A, Magnus V, Horvat S, Sandberg G (1993) Synthesis of the $\beta$-D glucosyl ester of [carbonyl-13C]-indole-3-acetic acid. J Label Comp Radiopharmac XXXIII:933-939

Jakubowska A, Kowalczyk S (2004) The auxin conjugate 1- $O$-indole3 -acetyl- $\beta$-D-glucose is synthesized in immature legume seeds by IAGlc synthase and may be used for modification of some high molecular weight compounds. J Exp Bot 55:791-801

Jakubowska A, Kowalczyk S (2005) A specific enzyme hydrolyzing 6- $O(4-O)$-indole-3-ylacetyl- $\beta$-D-glucose in immature kernels of Zea mays. J Plant Physiol 162:207-213

Jakubowska A, Kowalczyk S, Leźnicki AJ (1993) Enzymatic hydrolysis of 4- $O$ and 6- $O$-indol-3-ylacetyl- $\beta$-D-glucose in plant tissues. J Plant Physiol 142:61-66

Jensen PJ, Bandurski RS (1994) Metabolism and synthesis of indole3-acetic acid (IAA) in Zea mays. Levels of IAA during kernel development and the use of in vitro endosperm systems for studying IAA biosynthesis. Plant Physiol 106:343-351

Kai K, Horita J, Wakasa K, Miyagawa H (2007) Three oxidative metabolites of indole-3-acetic acid from Arabidopsis thaliana. Phytochemistry 68:1651-1663

Kęsy JM, Bandurski RS (1990) Partial purification and characterization of indol-3-ylacetylglucose: myo-inositol indol-3-ylacetyltransferase (indoleacetic acid-inositol synthase). Plant Physiol 94:1598-1604

Kowalczyk S, Bandurski RS (1990) Isomerization of 1-O-indol-3ylacetyl- $\beta$-D-glucose. Enzymatic hydrolysis of $1-O, 4-O$, and $6-O$ - indol-3-ylacetyl- $\beta$-D-glucose and the enzymatic synthesis of indole-3-acetyl glycerol by a hormone metabolizing complex. Plant Physiol 94:4-12

Kowalczyk S, Bandurski RS (1991) Enzymic synthesis of 1-O-(indol3 -ylacetyl)- $\beta$-D-glucose. Purification of the enzyme from Zea mays, and preparation of antibodies to the enzyme. Biochem $\mathbf{J}$ 279:509-514

Kowalczyk S, Jakubowska A, Zielińska E, Bandurski RS (2003) Bifunctional indole-3-acetyl transferase catalyses synthesis and hydrolysis of indole-3-acetyl-myo-inositol in immature endosperm of Zea mays. Physiol Plant 119:165-174

Leźnicki AJ, Bandurski RS (1988) Enzymic synthesis of indole-3acetyl-1- $O-\beta$-D-glucose. I. Partial purification and characterization of the enzyme form Zea mays. Plant Physiol 88:1474-1480

Leźnicki AJ, Bandurski RS (2001) The new pathway for the biosynthesis of ester linked IAA conjugates. XXXVI Meeting of the Polish Biochemical Society, Abstract, pp 302-303

Li AX, Steffens JC (2000) An acyltransferase catalyzing the formation of diacylglucose is a serine carboxypeptidase-like protein. Proc Natl Acad Sci USA 97:6902-6907

Ljung K, Östin A, Lioussanne L, Sandberg G (2001) Developmental regulation of indole-3-acetic acid turnover in Scots pine seedlings. Plant Physiol 125:464-475

Ljung K, Hull AK, Kowalczyk M, Marchant A, Celenza J, Cohen JD, Sandberg G (2002) Biosynthesis, conjugation, catabolism and homeostasis of indole-3-acetic acid in Arabidopsis thaliana. Plant Molec Biol 49:249-272 
Ludwig-Müller J (2011) Auxin conjugates: their role for plant development and in the evolution of land plants. J Exp Bot 62:1757-1773

Ludwig-Müller J, Walz A, Slovin JP, Epstein E, Cohen JD, Dong W, Town CD (2005) Overexpression of maize IAGLU in Arabidopsis thaliana alters plant growth and sensitivity to IAA but not IBA and 2, 4-D. J Plant Growth Regul 24:127-141

Michalczuk L, Bandurski RS (1980) UDP-glucose: indoleacetic acid glucosyl transferase and indoleacetyl-glucose: $m y o$-inositol indoleacetyl transferase. Biochem Biophys Res Commun 93:588-592

Michalczuk L, Bandurski RS (1982) Enzymic synthesis of 1- $O$-indol3 -ylacetyl- $\beta$-D-glucose and indol-3-ylacetyl-myo-inositol. Biochem J 207:273-281

Mugford ST, Qi X, Bakht S, Hill L, Wegel E, Hughes RK, Papadopoulou K, Melton R, Philo M, Sainsbury F, Lomonossoff GP, Roy AD, Goss RJM, Osbourn A (2009) A serine carboxypeptidase-like acyltransferase is required for synthesis of antimicrobial compounds and disease resistance in oats. Plant Cell 21:2473-2484

Oetiker JH, Aeschbacher G (1997) Temperature-sensitive plant cells with shunted indole-3-acetic acid conjugation. Plant Physiol 114:1385-1395

Ogita ZI, Markert CL (1979) A miniaturized system for electrophoresis on polyacrylamide gels. Anal Biochem 99:233-241

Percival FW, Bandurski RS (1976) Esters of indole-3-acetic acid from Avena seeds. Plant Physiol 58:60-67

Piskornik Z, Bandurski RS (1972) Purification and partial characterization of a glucan containing indole-3-acetic acid. Plant Physiol 50:176-182

Seidel C, Walz A, Park S, Cohen JD, Ludwig-Müller J (2006) Indole3-acetic acid protein conjugates: novel players in auxin homeostasis. Plant Biol 8:340-345

Slovin JP, Bandurski RS, Cohen JD (1999) Auxin. In: Hooykaas PJJ, Hall MA, Libbenga KR (eds) Biochemistry and molecular biology of plant hormones, Elsevier Science BV, pp 115-140

Starzyńska, Kowalczyk (2007) Transfer of indole-3-acetic acid from 1-O-IA-glucose to myo-inositol and to some mono- and oligosaccharides. In: 3rd Conference of Polish Society of Exp Plant Biol, Abstract, pp 118
Staswick PE, Serban B, Rowe M, Tiryaki I, Maldonado MT, Maldonado MC, Suza W (2005) Characterization of an Arabidopsis enzyme family that conjugates amino acids to indole-3acetic acid. Plant Cell 17:616-627

Stehle F, Brandt W, Schmidt J, Milkowski C, Strack D (2008) Activities of Arabidopsis sinapoylglucose:malate sinapoyltransferase shed light on functional diversification of serine carboxypeptidase-like acyltransferases. Phytochemistry 69:1826-1831

Stehle F, Brandt W, Stubbs MT, Milkowski D, Strack D (2009) Sinapoyltransferases in the light of molecular evolution. Phytochemistry 70:1652-1662

Szerszen JB, Szczyglowski K, Bandurski RS (1994) iaglu, a gene from Zea mays involved in conjugation of growth hormone indole-3-acetic acid. Science 265:1699-1701

Szmidt-Jaworska A, Kęsy J, Kopcewicz J (1997) Transformation of 1 - $O$-(indole-3-acetyl)- $\beta$-D-glucose into di- $O$-(indole-3-acetyl)-Dglucose catalysed by enzyme preparation from corn seedlings. Acta Biochim Pol 44:215-220

Tam YY, Epstein E, Normanly J (2000) Characterization of auxin conjugates in Arabidopsis. Low steady-state levels of indole-3acetyl-aspartate, indole-3-acetyl-glutamate, and indole-3-acetylglucose. Plant Physiol 123:589-595

Terol J, Domingo C, Talón M (2006) The GH3 family in plants: genome wide analysis in rice and evolutionary history based on EST analysis. Gene 371:279-290

Ueda M, Bandurski RS (1974) Structure of indole-3-acetic acid myoinositol esters and pentamethyl-myoinositols. Phytochemistry $13: 243-253$

Walz A, Park S, Slovin JP, Ludwig-Müller J, Momonoki YS, Cohen JD (2002) A gene encoding a protein modified by the phytohormone indoleacetic acid. Proc Natl Acad Sci USA 99:1718-1723

Wang H, Tian C-e, Duan J, Wu K (2008) Research progresses on GH3 s, one family of primary auxin-responsive genes. Plant Growth Regul 6:225-232

Woodward AW, Bartel B (2005) Auxin: regulation, action, and interaction. Ann Bot 95:707-735 